- Wasisto Raharjo Jati

Lembaga Ilmu Pengetahuan Indonesia

\title{
Dari Materialisme Ke Identitas: Transformasi Radikalisme Kelas Menengah Muda
}

\begin{abstract}
A B S T R A C T
The terminology of radicalism had been accepted largery as physical expression aims to create violence and riots. Radicalism is understood as informal style to negotiate when formal politics unsuccessfully created resolution. The young middle class were categorized vulnerable groups which easily infiltrated within several of ideologies. However, it is important to be noted that radicalism is a way to make expression space for youth people. The role of social media altered characteristic of movement that become rigorious. By using both perspective namely new social movement dan resources mobilization, this article aimed to analyse great transformation on radicalism nowadays.
\end{abstract}

Keywords: Radicalism, Young middle class, Materialsm, and Identity

\section{A. Pendahuluan}

"Beri aku 10 pemuda, niscaya akan kuguncangkan dunia" begitulah petikan pidato Bung Karno dalam melihat arti penting pemuda masa kini. Kelompok pemuda banyak terlibat dalam konstelasi sosial-politik Indonesia yang itu sebenarnya dapat dilihat dalam kemunculan berbagai macam gerakan mulai dari generasi angkatan 1920, 1928, 1945, 1966, 1974, 1998, hingga 2014. Setiap tahun tersebut sebenarnya mencerminkan adanya gerakan pemuda yang itu mempengaruhi dan merubah narasi sejarah bangsa. Namun demikian, idealisme pemuda Indonesia kini perlahan mulai mengikis dan tereduksi dengan semakin menggejalanya pragmatism dan budaya instan yang itu merupakan bagian dari modernitas. Pemuda telah menjadi gerbong besar terbentuknya kelas menengah Indonesia yang diisi sebagian besar diisi kalangan profesional semisalnya kalangan akademisi, eksekutif muda, maupun kalangan praktisi. Modernitas yang menginsyarakatkan adanya linearitas dalam kehidupan ternyata menimbulkan adanya distorsi dan alienasi terhadap kehidupan (Naisbitt, 1990). Munculnya paham radikalisme yang berkembang saat ini sebenarnya merupakan bagian dari tumbuhnya perlawanan modernitas yang telah menjadi wacana hegemonik tersebut. Posisi kelas menengah muda yang kemudian direlasikan dengan aksi radikalisme sebenarya juga mengikuti trend aksi kekerasan kini mulai bergeser menuju segmen menengah ke atas (Alvara, 2017). Hal utama yang ingin ditekankan pula terkait dengan istilah radikalisme yang akan dan menjadi kerangka analisis bukanlah merujuk pada aksi aksi ekstrimisme maupun . Namun lebih aksi penyuaraan aspirasi yang itu berjenjang dari level mendasar sekedar 
aksi gerakan damai hingga yang terakhir adalah revolusi. Sebelumnya aksi radikalisme berlangsung melalui segmen penduduk miskin yang menjadi isu hangatnya adalah ketimpangan dan kemiskinan. Namun ketika praktik kekerasan dan radikalisme tersebut dilakukan oleh kalangan kelas menengah adalah masalah eksistensi identitas dan idealitas. Ada rasionalitas yang berusaha digerakkan dalam kelas menengah ini adalah upaya proyeksi terhadap keamanan dan kebutuhan di masa depan. Hal tersebut yang kemudian menciptakan uopia mengenai ancaman. Pada akhirnya kemudian ide-ide tersebut tersebar meluas melalui media sosial sebagai perantara.

Peran sosial media dalam menginisiasi, membentuk, dan mengorganisir menjadi salah referensi alternatif membentuk gerakan politik radikalisme di antara kalangan kelas menengah muda (Dja'far, 2017). Bisa dikatakan bahwa sosial media pada hari ini merupakan pilar kelima demokrasi setelah lembaga trias politika dan pers. Dengan kata lain sebenarnya, kelas menengah melalui sosial media berusaha untuk menekankan kembali pentingnya demokrasi substantif dalam masa kekinian. Semula hadirnya sosial media yang hanya digunakan untuk pemenuhan kebutuhan hiburan di waktu senggang (leisure \& pleasure), kini berkembang menjadi alat gerakan politik penting. Melalui sosial media, kesadaran politik kemudian ditumbuhkan dan dikuatkan di kalangan kelas menengah muda. Mereka kemudian mampu untuk merespons dan mengkritisi kondisi sekitar melalui media sosial karena menawarkan adanya pertarungan ide kritis. Hal itulah yang kemudian menciptakan amplikasi ide dan gagasan dengan cepat menyebar di sosial media. Konteks politik global juga mempengaruhi transformasi gerakan politik seperti halnya gerakan \#Occupy dan gerakan Arab Springs merupakan dua contoh penting gerakan yang dilahirkan melalui pesan berantai melalui sosial media yang berkembang dalam gerakan politik (Jati, 2016).

Dalam konteks Indonesia, munculnya kelas menengah Indonesia adalah segmen kelas masyarakat yang terdidik dan juga berpikiran kritis terbentuk karena penetrasi media sosial dalam kehidupan (Jati, 2015). Mereka sebelumnya adalah kelompok masyarakat yang terbentuk karena momentum pertumbuhan ekonomi sehingga membentuk strata ekonomi berbeda dengan masyarakat lainnya. Hal itulah yang berdampak pada watak urtama kelompok kelas menengah yang senantiasa dependen dengan negara. Kondisi tersebut yang berdampak pada pembentukan nalar politik kelas menengah Indonesia yang lebih pragmatis, instan, self-oriented, dan lebih mengarahkan pada praktik politik reaksioner. Pengertian kelas menengah yang digunakan dalam tulisan ini adalah kelompok masyarakat Indonesia yang berbasis di metropolitian, bekerja di sektor formal/informal, digital savvy, dan juga berpenghasilan menengah-atas.Adanya identifikasi tersebut diperlukan untuk menyederhanakan makna kelas menengah yang selama ini masih ambigu dalam kajian sosial politik Indonesia. Permasalahan tersebut terjadi lantaran karena pemahaman kelas menengah sendiri masih tercampur adukkan antara observasi masyarakat dan konsep borjuasi. Maka perlu ditekankan bahwa tidak selamanya kelas menengah itu borjuasi, karena pada dasarnya mereka adalah kelompok masyarakat jemuk yang kemudian mendirikan adanya batas-batas demarkasi sosial yang membedakannya 
dengan masyarakat lainnya baik dari segi konsumsi, bahasa, maupun juga interaksi.

Titik tekan analisis utama dalam tulisan ini sebenarrnya adalah penggunaan media sosial yang secara aktif dan pasit berkembang menjadi alat penting penyebaran isu dan ideologi radikalisme pemuda. Transformasi dalam gerakan politik yang berkembang dalam situasi kekinian bukan lagi mengarah pada perebutan kekeuasan, namun lebih kepada aksi pemenuhan kepentinga. Selain itu bukan lagi ditampilkan dalam bentuk terorganisir, akan tetapi pada bentuk aksi sporadis dan instan. Transformasi tersebut merupakan bagian dari berkembangnya arus politik digital yang berada di Indonesia yang diinisasi oleh kelas menengah Indonesia. Berkembangnya politik digital di Indonesia sendiri bukanlah suatu fenomena, namun secara perlahan berkembang secara signikan sebagai alat artikulasi politik.

Pengertian radikalisme yang digunakan dalam tulisan ini tidaklah merujuk pada bentuk aksi konfliktual yang sifatnya ekstrimis dan konservatif. Radikalisme khususnya yang terjadi di kalangan anak muda pada dasarnya adalah respons terhadap keadaan baik itu di lingkungan keluarga, lingkungan sosial, maupun lingkungan negara yang direspons beragam. Munculnya gerakan anak muda yang terpublikasi luas gerakan N30, gerakan S26, dan lain sebagainya sebenenarnya adalah cara anak muda menengah berusah bertindak "radikal" dalam pengertian mereka sendiri. Namun lebih kepada upaya koersif dan represif oleh anak muda untuk mengekpresikan identitas dan keinganan mereka secara politik informal yang selamia ini kalah suara dengan kalangan senior dengan pendekatan elitisnya (Gordon, 1974). Hal tersebut kemudian ditunjukkan dengan beragam aksi unjuk diri yang berusaha untuk mencerminkan maskulinitas dalam ruang publik. Terlebih lagi bagi kalangan kelas menengah muda yang berusaha untuk meluapkan rasionalitas dan independensinya dalam penciptaan, Implikasinya adalah munculnya beragam bentuk radikalisme yang beraneka ragam tersebut mulai dari level budaya popular, gerakan non kekerasan, maupun gerakan ekstrem yakni gerakan bersenjata. Ekspresi radikalisme yang paling kentara sekarang ini diekspresikan melalui terminology jihad selfie yang dicetuskan oleh Noor Huda Ismail untuk menunjukkan regenerasi terorisme yang kini menggejala di kalangan anak muda. Maka, tulisan ini secara garis besarakan mengelaborasi lebih lanjut transformasi model gerakan tersebut dan juga radikalisme yang menggejala di kalangan anak muda.

\section{Transformasi Gerakan Radikalisme : Dari Ideologi ke Identitas}

Tren berkembangnya paham radikalisme sendiri mengalami bentuk pergeseran yang cukup signifikan yang semula melihat masalah ideology menjadi basis penting kini berkembang menjadi masalah identitas. Secara etimologis, radikalisme berasal dari kata "radic" yang berarti kembali ke akar (Nashir, 2017). Makna kembali ke akar sendiri sebenarnya juga mengandung makna multi inpretatif yang itu bisa bersinggungan dengan aspek sosiologi, teologis, maupun juga psikologis. Dalam berbagai kajian akademik, makna kembali ke akar itu erat kaitannya dengan kembali pada pemaknaan hidup sesuai dengan Qur'an dan Hadist. Namun sebenarnya makna kembali ke akar sebenarnya mengajak pada ketauhidan Islam. Pengertian radikalisme anak muda yang ingin ditekankan pada tulisan ini lebih 
melihat adanya transisi isu yang semula berbasis pada masalah etnisitas dan kelas, kini mengarah pada identitas (Wali, 2013). Dari situlah, kemudian sebenarnya makna mengenai tauhid tersebut yang kemudin diikuti dengan sikap tidak mau berkompromi, dan memutlakkan pemikirannya menjadi inti sebenarnya dari radikalisme. Pengejaran idealitas yang pada umumnya dipengaruhi adanya idealitas sempit itulah yang menjadi inti dasar radikalisme. Terkhusus bagi radikalisme yang menggejala di kalangan kelas menengah muda Indonesia lebih banyak dipengaruhi pemahaman agama yang sifatnya literal dan leksikal melalui media sosial.

Adanya perubahan tersebut sebenarnya juga dimaknai adanya perubahan signifikan dalam perebutan mencari materi tersebut. Pada dasarnya aksi radikalisme khususnya yang dilakukan oleh tersebut dapat digolongkan dalam berbagai motivasi. 1) radikalisme itu muncul sebagai bentuk respons terhadap tekanan represif, 2) radikalisme tersebut muncul karena kebutuhan materi, 3) radikalisme muncul karena kebutuhan adanya idealitas ruang eskpresi. 4) radikalisme sebagai bentuk ekspresi kekerasan. Keempat bentuk radikalisme tersebut dapat dikategorisasikan baik sebagai kegiatan revolusioner maupun tidak (MacLaughlin, 2012). Radikalisme yang selama ini muncul dalam berbagai aksi maupun narasi sebenarnya menawarkan adanya pilihan alternatif terhadap sistem yang telah selama ini eksis dengan dirubah melalui cara represif. Hal terpenting untuk dicatat dari perilaku radikalisme tersebut adalah upaya pemaksaan dan perubahan terhadap kondisi yang ada menurut idealitas tertentu. Cara-cara tersebut pada umumnya sering dilakukan dalam bentuk aksi revolusi yang itu sebenarnya mengarah pada bentuk perebutan kekuasaan. Berbagai macam revolusi kemudian berhasil merubah negara dimulai gagasan anak muda yang sebenarnya terindoktrinasi dan terpengaruhi pengalaman sama di negara yang berbeda. Radikalisme diidentikkan sebagai cara mutakhir dalam melakukan gerakan perubahan politik manakala perundingan dengan cara politik formal mengalami kebuntuan. Kondisi itulah kemudian mengilhami sekian banyak bentuk gerakan revolusioner di berbagai tempat. Adapun terkait dengan ketiga kecenderungan tren radikalisme tersebut, semuanya kembali pada kebutuhan yang ingin digerakkan dan dipenuhi oleh pemuda tersebut. Maka apabila dijelaskan dalam tabulasi secara lebih komprehensif, dapat dijelaskan sebagai berikut ini.

Tabel 1 : Bentuk Ekspresi dan Radikalisme Kelas Menengah Muda

\begin{tabular}{|l|l|l|l|}
\hline No & Bentuk Ekspresi Radikalisme & Bentuk Praktik Radikalisme & $\begin{array}{l}\text { Contoh Gerakan } \\
\text { Radikalisme }\end{array}$ \\
\hline 1 & $\begin{array}{l}\text { Radikalisme sebagai respons } \\
\text { tekanan represif }\end{array}$ & $\begin{array}{l}\text { Demonstrasi, penyampaian } \\
\text { petisi, maupun orasi kritis }\end{array}$ & $\begin{array}{l}\text { Gerakan demo jalanan } \\
\text { (street level } \\
\text { parliament), gerakan } \\
\text { blockade, maupun } \\
\text { gerakan aksi mogok }\end{array}$ \\
\hline 2 & $\begin{array}{l}\text { Radikalisme sebagai bentuk } \\
\text { kebutuhan materi }\end{array}$ & $\begin{array}{l}\text { Aksi penjarahan, } \\
\text { Aksi pencurian (robbery) } \\
\text { Aksi perampasan (grabbing) }\end{array}$ & $\begin{array}{l}\text { (land grabbing) } \\
\text { Sindikasi kartel / mafia }\end{array}$ \\
\hline
\end{tabular}




\begin{tabular}{|l|l|l|l|}
\hline 3 & $\begin{array}{l}\text { Radikalisme muncul kebutuhan } \\
\text { idealitas dan ruang eskpresi. }\end{array}$ & $\begin{array}{l}\text { Sentimen politik identitas } \\
\text { Aksi kebencian (hate speech) }\end{array}$ & $\begin{array}{l}\text { Gerakan aksi massa } \\
\text { (mobocracy) }\end{array}$ \\
\hline 4 & $\begin{array}{l}\text { Radikalisme sebagai eskpresi } \\
\text { kekerasan }\end{array}$ & $\begin{array}{l}\text { Aksi chauvinisme } \\
\text { Aksi penghakiman massa } \\
\text { (mass judgement) }\end{array}$ & $\begin{array}{l}\text { Riots (huru-hara), aksi } \\
\text { amuk massa, dan lain } \\
\text { sebagainya. }\end{array}$ \\
\hline
\end{tabular}

\section{Sumber : (Ali, 2015 ; Farhaan, 2015) dengan penambahan penulis}

Melalui empat sumber itulah sebenarnya, radikalisme kemudian bersumber dan menggejala di kalangan kelas menengah muda hari ini. Masing-masing praktik dan bentuk radikalisme tersebut memiliki karakteristiknya masing-masing. Namun analisis penting yang ingin ditonjolkan dalam menggarisbawahi empat hal tersebut sebenarnya terletak pada seberapa kuat isu atau masalah itu diperbincangkan dan menubuh dalam masyarakat dan seberapa kuat materi sumber daya yang digerakkan dalam melakukan gerakan tersebut. Kedua premis itulah yang sebenarnya penting untuk dilihat untuk mengukur seberapa intensitas radikalisme tersebut mengakar dalam masyarakat. Dikarenakan pada dasarnya, pemikiran radikalisme sendiri tidak akan berjalan dan berkembang kalau tidak ada unsur pendukung yang kuat pula. Selama ini dalam konstelasi politik Indonesia, pendanaan suatu aksi masa yang dilakukan kelas menengah berbasiskan pada faktor pembiayaan secara sukarela. Seberapa kuat motivasi dalam menyumbang dana tersebut juga kembali pada penerimaan masalah dalam masyarakat. Sekarang ini yang menjadi tren dalam melihat pola radikalisme adalah menguatnya sentimen identitas. yang justru membentuk adanya sikap sentimen identitas terhadap individu dan kolektif dari kalangan minoritas.

Dari keempat indikator mengenai bentuk dan perilaku mengenai radikalisme tersebut. Radikalisme berbasis identitas merupakan hal yang sekarang ini berkembang menjadi tren dalam masyarakat Indonesia. Hal tersebut sebenarnya merupakan tindak lanjut dari Masalah identitas dapat berkembang menjadi payung akan masalah lain yang lebih mikro untuk dipenuhi kepentingannya. Pemaksaan suatu identitas yang kemudian berkembang dalam bentuk gerakan radikalisme bisa menjadi sinyalemen negatif terhadap perkembangan demokrasi. Dengan kata lain sebenarnya, radikalisme juga berkembang dari pola esklusifitas tersebut yang berimplikasi pada masalah supremasi dan subordinasi. Radikalisme berbasis identitas ini menawarkan adanya daya sugestif dan intimidatif yang begitu kuat pengaruhnya dalam mengajak kelas menengah untuk hadir.

Pada akhirnya, kemudian radikalisme berbasis identitas tersebut berkembang dalam bentuk pola pikir biner semisalnya "kafir-non kafir, "Islam versus thagut", "pribumi dan non pribumi”, yang secara sepenuhnya dipengaruhi ideology jihadis tanpa kenal kompromi (Asghar, 2016). Pada intinya adalah munculnya pemikiran biner tersebut adalah kontestasi identitas yang dibalut dalam bentuk aksi pemenuhan kepentingan. Secara garis besar, radikalisme yang menggejala di kalangan kelas menengah pada dasarnya upaya melawan segala bentuk formalitas dan sikap permisif yang selama ini diatur dan digunakan oleh rezim pemerintah yang berkuasa. Kondisi itulah yang kemudian melahirkan berbagai 
macam bentuk pembangkangan yang dilakukan oleh kelas menengah muda yang menilai adanya perubahan itu harus untuk dilakukan.

Dari ketiga bentuk motivasi radikalisme tersebut, hal terpenting yang penting untuk dicatat adalah civil disobedient dan juga civil disengagement (Rawashamy, 2015). Kedua bentuk ekspresi tersebut merupakan bentuk riil yang dilakukan oleh kelas menengah muda hari ini. Dalam bahasa radikalisme, civil disobedient adalah bentuk pembangkangan terhadap berbagai aturan dan norma yang selama ini telah dianggap baku dan radikal. Hal yang paling sering dipertentangkan adalah aturan yang ada dan eksis di masyarakat selama ini lebih benilai duniawi maupun ukhrawi. Oleh karena itulah, pengedepanan dan formalisasi syariah dalam hukum positif menjadi hal yang tidak terelakkan. Radikalisme dalam bentuk civil disobedient merupakan bentuk yang paling awal dan sederhana yakni masih berupaya negosiasi dengan sistem yang ada. Sedangkan civil disengagement lebih mengarahkan kepada bentuk aksi represif dengan membentuk aksi represif dan koersif. Adapun radikalisme identitas tersebut dikaitkan dengan kedua bentuk praksis tersebut, sebenarnya lebih pada pertarungan identitas di ruang publik. Ada permainan logika mayoritas-minoritas minoritas yang sebenarnya digunakan dalam menjembatani adanya radikalisme tersebut di kalangan kelas menengah muda hari ini. Adanya kedua bentuk tersebut yakni civil disobedient maupun juga civil disengagement tersebut yang menjadi bagian dari narasi penting radikalisme kelas menengah muda tersebut dapat dianalisis dalam tabulasi berikut ini. 
Tabel 2 : Parameter Gerakan Radikalisme

\begin{tabular}{|l|l|l|}
\hline Paramater Gerakan & Civil Disobedient & Civil Disengagement \\
\hline $\begin{array}{l}\text { Pemahaman } \\
\text { Radikalisme }\end{array}$ & Negosiasi & Revolusi \\
\hline Resistensi & Represif & Koersif \\
\hline Perubahan Sosial & Solusi Kuratif & Solusi Alternatif \\
\hline Masa Gerakan & Temporer & Aliansi \\
\hline Pembentukan Gerakan & Berbasis Isu & Berbasis Kepentingan \\
\hline Basis Pembentukan & Figuritas & Figuritas \\
\hline
\end{tabular}

\section{Sumber : (Picardo, 1997) dengan penambahan penulis}

Dari penjelasan mengenai tabulasi tersebut, dapat dijelaskan bahwa potensi radikalisme yang berkembang di kalangan kelas menengah muda ternyata bermakna ganda baik itu yang sifatnya masih lunak maupun garis keras. Pertanyaan penting yang perlu ditekankan pula dalam membedah radikalisme tersebut adalah sebenarnya seberapa isu dan kepentingan yang terjaga dan terbalut dalam pemikiran kelas menengah muda hari ini. Sekarang ini yang menjadi pemahaman radikalisme arus utama adalah kebutuhan untuk diakui dan diafirmasi oleh negara. Hal itulah yang kemudian diikuti dengan munculnya berkembangnya pula ikon-ikon popular baik kiri maupun kanan yang mendominasi pemikiran kelas menengah muda hari ini mulai dari Che Guevara, Mao Zedong, Lenin, Hassan Al-Banna, maupun lain sebagainya. Pada intinya sebenarnya diseminasi radikalisme sebenarnya juga berkembang dalam bentuk pop culture . Dengan kata lain sebenarnya jika mengkritisi lebih lanjut, pemahaman radikalisme yang berkembang di kalangan kelas menengah muda sendiri apakah masih dimaknai secara selebrasi atau institusi. Kondisi tersebut dikarenakan radikalisme dalam konteks kekinian justru lebih banyak dimaknai sebagai aksi perayaan kekerasan kolektif di ruang publik dibandingkan dengan upaya membangun narasi perubahan.

\section{Transformasi Gerakan Radikalisme Muda : Politik Konvensional ke Politik Digital}

Esensi hadirnya gerakan politik sebenarnya adalah aksi kolektif membangun dan membentuk adanya perubahan sosial politik. Perubahan tersebut terkait dengan dengan adanya pemenuhan kepentingan ekonomi dan politik yang ingin dicapai. Pada dasarnya gerakan esensinya adalah "ruang antara" antara pemerintah dan masyarakat sipil untuk menegosiasikan dan mengartikulasikan kepentingan masing- 
masing untuk diselaraskan menjadi agenda bersama. Selain halnya berfungsi sebagai "ruang antara", gerakan juga memberikan pemaknaan mengenai keterhubungan dan juga kebersamaan (connectedness) (Triwibowo, 2006 : 6). Adapun makna kebersamaan (connectedness) dikaitkan dalam bentuk artikulasi radikalisme adalah menguatnya sentiment kebencian berbasis identitas yang cukup berpengaruh dan signifikan melalui sosial media. Kolektivitas menjadi kata kunci penting dalam membedah gerakan baik dari segi teoritis maupun praksis gerakan radikalisme. Terlebih lagi melalui persebaran media sosial sendiri memungkinkan adanya persebaran ide dan gagasan. Secara teoritis, kolektivitas merupakan tindak lanjut dari komunalitas yang kemudian terorganisir dalam satu barisan. Sedangkan, secara praksis, kolektivitas adalah bagian dari strategi merumuskan berbagai macam kepentingan menjadi satu kesatuan. Sebenarnya tema gerakan khususnya yang dilakukan oleh kelas menengah muda sebenarnya selalu berkembang sesuai dengan kebutuhan masyarakat dan juga karakter rezim itu sendiri yang mempengaruhi relasi negara dan masyarakat. Gerakan adalah pilihan terakhir yang dilakukan oleh masyarakat manakala aspirasinya tidak terpenuhi dalam ranah politik formal. Oleh karena dalam studi politik, praktik informal seperti gerakan inilah yang sebenarnya memberikan pengaruh besar terhadap praktik demokrasi di Indonesia. Ranah politik informal sebenarnya merupakan poin penting peralihan dari basis konvensional menuju digital. Hal tersebut dikarenakan melalui media sosial pula, praktik formalitas dan otoritatif yang selama ini dianggap tabu dalam politik kemudian diangkat dan ditampung dalam media sosial. Dengan kata lain, media sosial tersebut adalah media ice breaker yang kemudian memasukkan informalitas tersebut dalam politik digital. Berbeda halnya demokrasi, radikalisme adalah bentuk anomali dan juga distorsi dalam memahami gerakan. Gerakan dalam demokrasi mengkristalkan dalam bentuk aksi perebutan kekuasaan baik itu secara konstitusional maupun inkonstitusional dalam level makro. Sedangkan gerakan dalam radikalisme secara mayoritas berorientasi destruktif, meskipun ada juga yang sifatnya konstruktif. Gerakan dalam radikalisme lebih berorientasi pada pemenuhan kepentingan pribadi dan kolektif yang disesuaikan melalui kebutuhan masing-masing.

Kondisi tersebut yang berimplikasi pada aksi kekerasan dan ketidakadilan yang terjadi dalam skala besar maupun kecil. Dalam hal ini terdapat dua mahzab yang penting untuk dilihat sebagai Analisis melihat gerakan politik yakni new social movement dan juga resources mobilization theory. Pada teori pertama, gerakan politik lebih berfokus pada pemenuhan isu dan kepentingan politik keseharian. Sedangkan pada teorisasi kedua lebih condong pada gerakan perebutan kekuasaan. Namun demikian, tulisan ini pula untuk melakukan revisi terhadap pola gerakan politik yang semula berbasis pada kolektivitas menuju konektivitas. Hal tersebut selaras dengan intensifikasi penggunaan sosial media untuk penyebaran paham-paham radikalisme yang memang kali ini disasar adalah kalangan anak muda.

Kedua elemen tersebut menjadi alasan penting gerakan politik menjadi 
penting untuk dilakukan. Munculnya gerakan politik yang secara garis besar muncul dari kalangan akar rumput tersebut sebenarnya merupakan respons skeptis publik terhadap proses politik formal yang terlalu birokratis,elitis, dan juga permisif. Kondisi itulah yang kemudian menciptakan ajang repreentasi populer bagi masyarakat sipil kepada negara sebagai muara. Adanya trend representasi popular tersebut sebenarnya menandai adanya pergeseran orientasi gerakan dari kontestasi kekuasaan menuju pada pemenuhan kepentingan yang terjadi pada masa paska otoritarian.

Adanya pergeseran tujuan terhadap gerakan politik tersebut menandai adanya pergseran secara teoritik dalam kajian ilmu politik. Semula kajian gerakan politik berada dalam dua pendekatan utama yakni non-social movement dan juga resources mobilization theory. Dalam pengertian sederhana teorisasi pertama melihat bahwa gerakan politik yang berkembang pada konteks kekinian tidak lagi berorientasi pada pemenuhan kepentingan kekuasaan maupun dimensi ekonomi-politik. Namun lebih kepada pemenuhan kebutuhan rekognisi maupun representasi identitas dalam ruang publik. Tipe gerakan ini lebih tepat untuk melihat adanya gerakan masyarakat sosial urban yang diinisasi oleh kelas menengah, gerakan ekologis, gerakan kelompok minoritas, maupun juga gerakan orang muda yang menitikberatkan pada kebutuhan otonomi dan identitas (Picardo, 1997 : 413).

Gerakan sosial baru pada dasarnya merupakan gerakan politik dalam masyaraakat post industri yang sebenarnya mengangkat isu keseharian. Masalah keseharian yang diangkat tersebut sebenarnya merupakan respons terhadap pengarustamaan aspirasi yang menjadi keijakan, namun tidak mengakar sampai akar rumput. Kondisi itulah yang sebenarnya menjadikan publik mengalami kebosanan sehingga berupaya membangun saluran alternatif. Hal itulah yang menjadikan masalah sehari-hari menjadi isu politik penting yang patut untuk dibicarakan dalam ruang publik. Konteks penting yang perlu digarisbawahi dalam melihat gerakan masa kini bahwa perubahan tidaklah selalu fundamental, namun juga masalah keseharian yang itu sebenarnya juga memiliki aspek penting. Kondisi tersebut sebenarnya merupakan respons dari era modernitas yang serba linier dan resiprokal berimplikasi pada normalitas dan absurditas kehidupan. Masalah itulah yang kemudian menimpa banyak kalangan kelas menengah muda yang berupaya melawan logika linearitas dan normalitas tersebut. Linearitas mengasumsikan bahwa kesuksesan dalam kehidupan dan normalitas bahwa ada parameter-parameter yang perlu dipenuhi. Artinya dengan bekerja keras adalah kunci utama mendatangkan adanya perubahan dalam msyarakat tersebut dimana menimbulkan adanya tuntutan-tuntutan yang lambat laun justru menciptakan adanya budaya kontestasi satu sama lainnya dalam realitasnya. Artinya dari kedua hal tersebut sebenarnya membawa implikasi kepada adanya resistensi anak muda yang berkembang dalam wujud radikalisme.

Maka, konteks tersebut kemudian memunculkan adanya logika antimainstream yang menjadi tren di kalangan kelas menengah muda. Gerakan sosial baru yang digagas oleh kelompok anak muda ini biasanya berwujud pada gerakan anti kemapanan, gerakan anti normalitas, 
maupun juga pada gerakan anti pendisplinan. Ketiga istilah dalam gerakan itulah yang kerap kali gerakan sosial baru selama ini. Adapun gerakan anti kemapanan tersebut merujuk pada gerakan kontra terhadap entitas atau pemahaman yang menilai bahwa kebahagiaan itu dicapai dengan kepemilikan modal dan materi. Sedangkan gerakan anti normalitas merujuk pada gerakan anak muda yang selama ini menentang dan resisten dengan pola pikir konservatif dan tradisional yang mengkonstruksi "kebenaran" dianggap hegemonik. Gerakan pendisplinan sendiri lebih condong kepada gerakan untuk melawan terhadap regulasi yang dianggap restriktif terhadap anak muda. Pada dasarnya gerakan politik anak muda lebih pada upaya membentuk ruang-ruang ekspresi diri maupun kolektif.

Ada pun teori new social movement kemudian menjelaskan kerangka gerakan anak muda dalam bentuk penciptaan ruangruang tersebut dapat dijelaskan dalam analisa sebagai berikut ini.

Tabel 3 : Perbandingan Bentuk Radikalisme Identitas

\begin{tabular}{|l|l|l|l|}
\hline No & $\begin{array}{c}\text { Indikator New Social } \\
\text { Movement }\end{array}$ & \multicolumn{1}{|c|}{$\begin{array}{c}\text { Gerakan Kolektif Radikalisme } \\
\text { Identitas }\end{array}$} & $\begin{array}{c}\text { Gerakan Konektif } \\
\text { Radikalisme } \\
\text { Identitas }\end{array}$ \\
\hline 1 & Isu keseharian & Masalah identitas & Masalah aktual \\
\hline 2 & Orientasi gerakan & Menjadi kelompok penekan & $\begin{array}{l}\text { Menjadi kelompok } \\
\text { kepentingan }\end{array}$ \\
\hline 3 & Saluran kepentingan & Representasi & Rekognisi \\
\hline 4 & Tujuan gerakan & $\begin{array}{l}\text { Membangun saluran aspirasi } \\
\text { informal }\end{array}$ & $\begin{array}{l}\text { Menyampaikan } \\
\text { aspirasi via media } \\
\text { sosial }\end{array}$ \\
\hline
\end{tabular}

\section{Sumber data : Turner, 2006 \& Foweraker, 1995}

Ketiga bentuk gerakan tersebut kemudian mengkristalkan diri dalam bentuk gerakan eksistensi diri dalam kelompok maupun individu. Sedangkan pada pengertian singkat mengenai resources mobilization theory dapat diartikan sebagai gerakan politik yang dilakukan secara mobilisasi institusional terhadap institusional lainnya dalam rangka redistribusi materi ekonomi politik (Foweraker, 1995). Dalam teorisasi ini sebenarnya, radikalisme yang berlangsung di kalangan kelas menengah muda berupaya untuk mengakumulasikan materi. Kondisi tersebut kemudian mengkristalkan diri dalam bentuk organisasi-organisasi kemasyarakatan yang menggunakan kekuatan paramiliter untuk menekan kepada sesama aktor politik. Sebenarnya kekuatan paramiliter tersebut Dalam konteks kekinian, radikalisme yang berkembang dalam gerakan new social movement sendiri lebih banyak didominasi dengan gerakan sporadis lebih mengedepankan aspek emosional berbasis 
sentiment identitas (Hisyam, 2008). Dalam berbagai hal sebenarnya, radikalisme dalam konteks kekinian sebenarnya lebih berkembang dalam bentuk voluntarisme.

Kondisi ini dikarenakan lebih mudah dan cepat daripada sekedar berkembang dalam bentuk organisasi. Oleh karena itulah yang menyebabkan bahwa radikalisme yang berkembang sekarang ini lebih sifatnya temporer yang basisnya di ruang tertentu. Memang kemudian ada yang bergerakan dalam skala makro. Namun peluangnya lebih besar dan berisiko karena menghadapi apparatus negara lintas bangsa. Pada akhirnya kemudian radikalisme dalam bentuk new social movement sendiri kemudian hanya berkembang parsial. Selain halnya parsial, pola lain yang bisa dianalisis adalah sifatnya yang temporer dan juga lebih mementingkan adanya pemenuhan kepentingan sesaat. Hal tersebut yang menjadi penting untuk dianalisis dalam melihat gerakan ini bahwa kepentingan menjadi titik penting bahwa ternyata radikalisme tersebut bisa dinegosiasikan dan dibangun jalur mediasinya melalui negara. Dikarenakan pada dasarnya capaian yang ingin dicapai dalam gerakan ini adalah representasi dan juga rekognisi yang selama ini belum dijamah oleh negara.

Berbeda halnya dengan new social movement yang lebih meyoroti isu dan identitas sebagai basis pemicu gerakan. Teori ini sebenarnya menekankan pada aspek pada institusionalisme dan kolektivitas sebagai sumber utama gerakan resources mobilization. Radikalisme kemudian mengalami eskalasi kepentingan yang lebih menyoroti pada pilihan terhadap terbentuknya institusional menjadi pilihan sahih dalam membuat suatu dengan perubahan sosial politik di masyarakat. Dalam hal ini, radikalisme di kalangan kelas menengah muda yang mengalami institusionalisasi sebenarnya mengarahkan diri kepada bentuk perebutan kekuasaan atau pengamanan sumber daya alam. Dengan kata lain, sebenarnya ini merupakan bentuk tindak lanjut dari radikalsime yang berkembang dalam bentuk new social movement (Turner, 2006).

Berkembangnya gerakan radikalisme yang sekarang ini banyak didominasi anak muda seperti halnya ISIS, Jamiah Internasional, Laskar Jihad, dan lain sebagainya sebenarnya adalah bagain dari upaya mencari ruang kekuasaan formal. Pada intinya yang menjadi target gerakan politik itu adalah institusi hegemonik yang selama ini berkuasa dengan membentuk lembaga alternatif. Radikalisme tersebut ditempuh karena negosiasi maupun juga advokasi yang dilakukan oleh kelompok organisasi masyarakat tersebut tidak memiliki solusi pasti ketika berhadapan dengan negara. Kondisi itulah yang menjadikan ide-ide radikalisme di kalangan kelas menengah muda kemudian menjadi solusi sahih terhadap perubahan sosial. Namun yang menarik kemudian adalah radikalisme hanya berkembang dalam bentuk instrumentasi terhadap ideologi besar yang menjadi payung besar semisalnya saja Islamisme, Environmentalisme, Liberalisme, maupun juga Populisme.

Berbagai macam ideologi itulah yang silih berganti mewarnai adanya gerakan radikalisme yang berkembang di Indonesia selama ini. Radikalisme tersebut secara sederhana diterjemahkan sebagai bentuk gerakan angkat senjata dengan menjadikan 
objek negara sebagai sasaran target. Meskipun tidak menutup kemungkinan dengan kelompok masyarakat lainnya yang menjadi korban kekerasan tersebut. Gerakan radikalisme berbasiskan pada analisa perspektif ini lebih berupaya menunjukkan kekerasan sebagai solusi utama dan berusaha menunjukkan kalau negara itu melemah. Oleh karena itulah dengan melemahnya fungsi dan kapasitas negara, secara otomatis gerakan radikalisme tersebut berusaha menyodorkan lembaga baru. Tawaran terbentuknya lembaga baru dan juga wacana yang ditawarkan menjadi kerangka penting dalam model gerakan ini. Namun demikian, hal yang perlu dicatat juga dalam pandangan teori ini adalah gerakan politik tersebut dilakukan dalam kerangka kelembagaan. Hal tersebut sebenarnya merupakan bagian dari cara menampung berbagai macam kepentingan masingmasing peserta gerakan. Selain juga sebagai wadah, pola lain yang perlu dijelaskan dalam resources mobilization ini adalah modelnya yang strukturalis dan juga closed recruitment. Hal tersebut mengindikasikan bahwa gerakan radikalisme juga berupaya membangun ideologi sebagai bagian dari kaderisasi. Kondisi itu sebenarnya merupakan bagian dari pembangunan soliditas dan solidaritas kelompok dalam memperjuangkan tujuannya yakni membuat revolusi.

Maka apabila dijelaskan secara lebih ringkas dan komprehensif mengenai watak gerakan radikalisme yang ditunjau dalam perspektif ini adalah negara dan perubahan menjadi target penting pencapaian gerakan yang perlu untuk ditangani lebih lanjut.

\section{Penutup}

Pembahasan mengenai radikalisme yang berkembang di kalangan kelas menengah muda pada akhirnya mengerucut pada masalah identitas yang menjadi basis masalahnya. Adanya transformasi dari materi menuju identitas sebenarnya mengindikasikan bahwa terdapat kebutuhan ruang yang semakin besar dan mendesak. Bagi kalangan muda sendiri, radikalisme adalah upaya untuk mendapatkan pengakuan dan juga tempat untuk bisa berekspresi lebih. Hal ini dikarenakan respons radikalisme yang berkembang lebih pada upaya melawan formalitas yang selama ini membelenggu. Oleh karena itulah, radikalisme juga identik dengan upaya melawan normalitasnormalitas yang selama ini dianggap baku. Dalam dua analisa teori yang telah dijabarkan di atas menunjukkan bahwa radikalisme sekarang ini bergerak bergerak antara materi dan identitas. Namun apabila dilihat dalam eskalasi dan aglomerasinya, radikalisme berbasiskan pada identitas yang kedepannya akan berkembang dalam ekspresi radikalisme anak muda.

$* * * * *$

\section{DAFTAR PUSTAKA}

Alvara Strategic \& Yayasan Mata Air, 2017, "Potensi Radikalisme di Kalangan Profesional Indonesia". Jakarta : Alvara.

Asghar, Ali. "Gerakan Terorisme Islam 2015" dalam Jurnal Keamanan Nasional 2(1) : 1-18.

Dja'far, Alamsyah. "Memahami Kelompok Rentan Intoleransi dan Radikalisme". Paper dipresentasikan dalam Diskusi 
Kelompok Kelas Menengah Muslim Perkotaan, 17 Oktober 2017.

Foweraker, Joe. 1995. Theorizing Social Movement. London : Pluto Press.

Gordon, Hava. 1974. We Fight to Win. Brunswick : Rutgers University Press.

Hisyam, Muhamad, 2008. Prosiding Muncul dan Berkembangnya Varian Keagamaan Islam Kontemporer di Indonesia. Jakarta : PMB Press.

Jati, Wasisto. "Aktivisme Kelas Menengah Berbasis Media Sosial 2016" dalam Jurnal Ilmu Sosial dan Ilmu Politik 20(2) : 147-162.

Jati, Wasisto. "Cyberspace, Internet, Dan Ruang Publik Baru: Aktivisme Online Politik Kelas Menengah Indonesia 2015". Jurnal Pemikiran Sosiologi 3(1) : 25-35.

Jati, Wasisto. 2016. "Gerakan Politik Masyarakat Sipil dalam Globalisasi Kontemporer" dalam Pamungkas, Globalisasi, \& Global Village. Jakarta : Di

MacLaughlin, Paul, 2012. Radicalism : A Philosophical Study. London : Palgrave.

Naisbitt, John, 1990. Megatrends: Ten New Directions Transforming Our Lives. New York : Amazon.

Nashir, Haedar. 2017."Moderasi sebagai Jalan Ketiga" dalam Darraz, Abdullah. Jihad, Khilafah, Terrorisme. Jakarta : Mizan.

Ramaswamy, Sushila. 2015. Political Theory : ideas and Concept. Delhi : Phi Learning

Turner, Jonathan. 2006. Handbook of Sociological Theory. London : Springer. .
Triwibowo, Darmawan, 2006. Gerakan Sosial : Wahana Civil Society bagi Demokratisasi Indonesia. Jakarta : LP3ES.

Wali, Farhaan. 2015. Radicalism Unveiled. London : Routledge. 